\title{
Pelaksanaan Hibah Harta Bercagar dalam Industri Perancangan dan Pengurusan Harta Orang Islam
}

\author{
Implementation of Collateral Hibah in the Muslim Wealth Management and \\ Planning Industry
}

NOOR LIZZA MOHAMED SAID*, WAN AMIRUL ADLI WAN AYUB ${ }^{1}$

\begin{abstract}
The credit convenience through loan installment made it easier for the society to own an unmovable property. However, the emerging issue of the matter is it also contributes to loads of frozen assets. The concept of hibah is being applied as introductory step in planning assets so it can continuously be benefitted. However, the policy practiced by the banks is still not allowing any charged property to be transferred through hibah besides the property as it also does not fully belong to the buyer. This research analyzes the implementation of hibah for charged property according to fuqaha's view and observe the product implementation in Malaysia Law. This research is conducted by qualitative method using document analysis as the design of the research. The findings indicated that hibah of charged property is valid according to some of the fuqaha's view with a few conditions. The differences in the verdicts of courts in Syariah Courts about the hibah cases however confirmed that hibah is being accepted in institutions. Few challenges and weaknesses have to be overcome to implement the product so that it can not be challenged by any party. The solution between hibah document provider and the loan provider has to be quickly executed in order for a guaranteed implementation of the product.
\end{abstract}

Keywords: product, hibah, mortgage, property management, Syariah Court

Pengurusan harta melalui instrumen hibah semakin mendapat perhatian masyarakat Islam sebagai langkah awal mengurus dan merancang harta. Hibah semakin giat dipopularkan sebagai instrumen pengurusan harta yang mampu mengatasi masalah berkaitan harta pusaka seperti lambakan harta beku, masalah harta tidak dituntut dan sebagainya. Kelebihan instrumen hibah yang tidak perlu melalui urusan pentadbiran yang merumitkan serta kos yang tinggi menjadikan instrumen tersebut lebih efektif dan memenuhi keperluan masyarakat setempat dalam menangani isu-isu yang berkaitan harta pusaka.

Pada hari ini, hibah dilihat sebagai satu fenomena baru dalam industri perancangan dan pengurusan harta orang Islam. Pelbagai produk berkonsepkan hibah telah ditawarkan sama ada dalam institusi kewangan Islam mahupun industri perancangan harta sebagai instrumen pengurusan harta ketika hidup. Salah satu daripadanya adalah produk hibah harta bercagar yang akan menjadi perbincangan artikel ini.

Pelaksanaan produk hibah harta bercagar bertujuan untuk membantu masyarakat menguruskan harta yang dibeli melalui pembiayaan pinjaman seperti rumah, hartanah dan kenderaan dengan lebih berkesan. Sekiranya produk ini mampu direalisasikan ia bukan sahaja

\footnotetext{
${ }^{1}$ Noor Lizza Mohamed Said* Ph. D (corresponding author), senior lecturer at Centre of Shariah Research, Faculty of Islamic Studies, Universiti Kebangsaan Malaysia, 43600 Bangi, Selangor, Malaysia, email: lizza@ukm.edu.my; Wan Amirul Adli Wan Ayub, Postgraduate Student at Centre of Shariah Research, Faculty of Islamic Studies, Universiti Kebangsaan Malaysia, 43600 Bangi, Selangor, Malaysia, email: amiruladli9402@gmail.com.
} 
dapat membantu masyarakat malah sebahagian besar daripada isu berkaitan harta pusaka boleh diselesaikan. Ini kerana realiti yang berlaku hari ini adalah rata-rata masyarakat Islam memiliki aset menerusi pembiayaan pinjaman bank yang memakan masa hampir 25 ke 30 tahun tempoh bayaran balik. Keadaan ini dilihat bakal berterusan untuk tempoh jangka masa yang panjang dan ia bakal memberikan kesan yang negatif kepada ekonomi negara umumnya sekiranya tiada perancangan lebih berkesan dilakukan. Tambahan pula kemudahan kredit yang tersedia pada hari ini dengan kewujudan inisiatif-inisiatif daripada kerajaan membolehkan masyarakat memiliki harta dengan lebih mudah (Bernama 2018).

Ini kerana apabila berlaku kematian kepada pembeli, harta yang ditinggalkan bersamasama dengan liabiliti perlu ditanggung oleh waris. Harta tersebut berkemungkinan akan dijual bagi mendapatkan balik wang pihak pembiaya pinjaman. Lebih parah lagi harta tak alih yang ditinggalkan terpaksa dibelah bahagi apabila waris tidak memahami konsep pengurusan harta dengan betul. Keadaan ini boleh menyebabkan kerugian kepada harta dan waris di samping menjadikan harta itu sendiri tidak ekonomik. Oleh yang demikian, hibah diaplikasikan sebagai langkah awal merancang harta untuk mengelakkan situasi seperti ini berlaku.

Secara amalannya, harta yang diperoleh melalui pembiayaan pinjaman bank akan dicagar kepada pihak bank (Rusnadewi \& Noor Inayah 2010) untuk dijadikan sekuriti bayaran balik hutang agar pinjaman dapat dilunaskan dengan nilai aset yang digadaikan sekiranya peminjam gagal melunaskan hutang yang berbaki (Resolusi Syariah Bank Negara Malaysia 2010). Apabila harta dicagar status pemilikan seseorang telah berubah. Pemilik tidak lagi memiliki kebebasan penuh untuk menguruskan hartanya kerana terikat dengan hak pihak lain kesan daripada pembentukan akad cagaran. Syarat utama harta hibah adalah harta tersebut mestilah milik sempurna pemberi hibah termasuklah kebebasan untuk melakukan sebarang transaksi tanpa boleh dihalang oleh mana-mana pihak. Dalam isu hibah harta yang masih dalam cagaran, seseorang tidak lagi dikatakan mempunyai kebebasan mutlak untuk mengurus hartanya kerana hak pemegang cagaran telah terbentuk. Ini menimbulkan persoalan tentang apakah kedudukan sebenar hibah harta cagaran di sisi syarak. Sejauh manakah hibah harta bercagar dibenarkan oleh syarak?

Meskipun pada asalnya pembeli merupakan pemilik terhadap harta namun, disebabkan pembentukan akad cagaran, syarak menghadkan transaksi yang dibenarkan bagi menjaga hak dan kepentingan pihak pemegang cagaran. Selama dalam tempoh berkenaan urus niaga yang boleh menggugat kepentingan pemegang cagaran adalah tidak dibenarkan termasuklah hibah (al-Hisny 2013: 443). Menurut Naziree (2011) harta alih atau tidak alih yang masih dalam cagaran tidak boleh dihibahkan kerana status harta tersebut masih dalam pembiayaan. Hal ini juga bertujuan untuk mengelakkan kemungkinan yang boleh mengurangkan nilai harta sedangkan harta tersebut menjadi sekuriti bayaran balik hutang (Rusnadewi \& Noor Inayah 2010).

Isu lain yang perlu diberi perhatian adalah pihak bank masih belum mengamalkan polisi yang membenarkan harta cagaran dipindah milik sama ada melalui hibah atau selainnya. Sekiranya bank membenarkan harta yang masih dalam cagaran dihibah ia memberikan kerugian kepada pihak mereka dan boleh mengundang pelbagai masalah pada masa akan datang. Sebagaimana kajian oleh Wan Kamal Mujani et al. (2012) mengatakan bahawa menjadi amalan dan polisi pihak institusi kewangan terutamanya pihak bank, tidak membenarkan transaksi pindah milik dibuat ke atas hartanah ataupun rumah yang masih dalam cagaran melainkan setelah pembayaran penuh telah dibuat. Pihak bank berhak untuk tidak mengambil risiko membenarkan harta yang masih dalam tempoh cagaran dihibah.

Justeru, artikel ini akan menganalisis pelaksanaan hibah harta bercagar berdasarkan pendapat para fuqaha dan mengkaji sejauh manakah penawaran produk tersebut mampu dilaksanakan dalam sistem pentadbiran dan perundangan Malaysia. 


\section{Pengurusan Harta Melalui Hibah}

Islam telah menggariskan secara jelas berkaitan pengurusan dan perancangan harta. Sama ada semasa hidup seperti wakaf, hibah, nazar dan sedekah atau selepas kematian seperti faraid dan wasiat. Pada hari ini masyarakat telah didedahkan dengan keperluan merancang harta semasa hidup terutama melalui konsep hibah bagi mengelakkan isu seperti lambakan harta beku, harta tidak dituntut dan sebagainya. Kelebihan hibah telah dihuraikan oleh beberapa kajian lepas sebagai alternatif dan pelengkap kepada sistem yang sedia ada.

Masyarakat Malaysia telah mengamalkan pemberian melalui hibah sejak dahulu lagi. Kajian Krippendorff (1980) menunjukkan hampir 32\% masyarakat memilih hibah sebagai instrumen pengurusan harta. Bahkan jika dilihat di negara maju seperti Amerika Syarikat keupayaan ibubapa memberi harta melalui hibah adalah tinggi bergantung kepada sumber pendapatan mereka (Nordblom and Ohlsson 2010). Ian (2008) menyebutkan hibah sudah menjadi keperluan umat Islam hari ini sebagai salah satu instrumen pengurusan harta semasa hidup bahkan ia sudah diamalkan di serata negara umat Islam. Jika dilihat amalan memberi hibah sudah diamalkan sejak zaman dahulu lagi namun, pada ketika itu pelaksanaannya lebih kepada pemberian melalui lisan sahaja dan tidak melalui dokumen bertulis.

Rusnadewi dan Nasrul (2013) menjelaskan kepentingan pengurusan harta melalui hibah adalah bertujuan untuk mengatasi masalah yang melanda umat Islam di Malaysia terutama dalam isu berkaitan harta pusaka. Kegagalan merancang harta semasa hidup menyebabkan harta tidak dapat dimanfaat oleh waris dan generasi seterusnya akibat daripada kelemahan dan kerumitan proses pentadbiran yang sedia ada serta sikap waris yang memandang ringan terhadap isu ini. Kefleksibelan instrumen hibah seperti tiada had, boleh diberikan kepada sesiapa sahaja memberi kemudahan kepada masyarakat untuk mengurus harta mereka lebih awal selari dengan perubahan adat dan keperluan masyarakat semasa. Oleh itu, hibah dilihat sebagai penyelesaian yang berkesan untuk dilaksanakan dan ia sangat bersesuaian dengan adat dan amalan masyarakat setempat.

Hibah telah digunakan secara meluas terutama sebagai alternatif untuk merancang harta. Gabungan di antara konsep amanah dan hibah sebagai instrumen perancangan harta boleh dihujahkan sebagai jalan keluar kepada permasalahan berkaitan harta pusaka dan ia telah diamalkan oleh kebanyakan syarikat amanah pada hari ini. Gabungan dua konsep ini membantu mempercepatkan proses pembahagian harta pusaka apabila harta tidak lagi dikategorikan sebagai harta pusaka kerana telah diberikan kepada penerima hibah melalui pemegang amanah semasa hayat pemberi (Akmal \& Tajul 2017). Frederik (2006) mengatakan gabungan amanah dan hibah adalah instrumen yang perlu dimanfaatkan oleh masyarakat Islam dalam menangani masalah-masalah berkaitan pusaka. Namun, konsep pelaksanaan hibah amanah perlulah diteliti kerana terdapat beberapa bentuknya yang bertentangan dengan perundangan Islam.

Menurut Nasrul et al. (2017) konsep hibah bersyarat berpotensi menjadi instrumen pengurusan harta yang lebih berkesan. Konsep hibah merupakan salah satu cara pelupusan harta yang diiktiraf dalam Islam dan dakwaan bahawasa hibah membelakangi sistem pusaka atau faraid perlu diperbetulkan. Ciri-ciri hibah yang tiada had kadar harta pemberian dan boleh diberikan kepada sesiapa sahaja sangat relevan untuk diguna pakai terutama bagi mereka yang hanya mempunyai waris perempuan sahaja. Ia juga turut membantu golongan muallaf dan keluarga angkat sama ada non-muslim atau muslim sendiri melalui pemberian hibah kerana golongan ini tidak layak untuk mewarisi harta si mati. Justeru, pengurusan harta melalui instrumen hibah bukan sahaja boleh mengatasi masalah pengurusan yang sedia ada bahkan ia juga boleh mengeratkan hubungan sosial dalam masyarakat.

Dalam membahaskan kedudukan hibah dalam konteks perundangan sivil di Malaysia, Wan Kamal Mujani et al. (2011) berpandangan bahawa hibah berpotensi sebagai instrumen pengurusan harta semasa hidup yang boleh diaplikasikan terutama untuk mengatasi masalah lambakan harta beku. Undang-undang tempatan turut mengiktiraf hibah sebagai salah satu kontrak yang terkandung di bawah Akta Kontrak 1950. Namun terdapat beberapa ciri yang membezakan hibah di bawah perundangan Islam dan sivil. Oleh itu, setiap isu yang berbangkit 
yang melibatkan harta orang Islam hendaklah dibicarakan di institusi yang lebih layak iaitu Mahkamah Syariah.

Meskipun hibah dihujah sebagai alternatif berkesan dalam pengurusan dan perancangan harta orang Islam, Noor Lizza et al. (2012) menekankan bahawa perlulah digubal satu undangundang khusus berkaitan hibah untuk dijadikan panduan oleh pihak industri dan individu persendirian. Impak daripada ketiadaan undang-undang yang membicarakan tentangnya secara khusus boleh menimbulkan kekeliruan kepada masyarakat terhadap kepelbagaian dan ketidakselarasan produk berkonsepkan hibah yang ditawarkan pada hari ini.

\section{Konsep Hibah Harta Cagaran}

Hibah harta bercagar mengguna pakai dua konsep utama dalam muamalat Islam iaitu konsep cagaran atau gadaian (al-rahn) dan konsep hibah. Cagaran merupakan salah satu akad yang dianjurkan dalam sistem kewangan Islam terutama bagi masyarakat yang berpendapatan rendah untuk memudahkan meraka mendapatkan kredit. Cagaran bermaksud menjadikan sesuatu 'ain sebagai jaminan atau pengikat hutang yang akan diambil daripadanya untuk melunaskan hutang ketika tidak dapat melangsaikannya (al-Sharbini 2009: 166). Dalam bahasa yang mudah, cagaran adalah situasi di mana penghutang meletakkan suatu barang yang bernilai untuk dijadikan jaminan bayaran balik hutang.

Cagaran dalam Islam boleh dilihat berdasarkan konsep al-rahn yang mana ia merupakan salah satu cara pemiutang memastikan haknya terjamin selain daripada kaedah menulis hutang dan mendatangkan saksi ketika akad hutang dibuat (Asmadi Mohamed Naim 2004). Hal ini boleh difahami melalui pensyariatan al-rahn dalam surah al-Baqarah ayat 282-283. Akad al-rahn adalah cara yang paling efektif dalam memastikan pembayaran balik hutang. Kedudukan harta cagaran sebagai sekuriti bayaran balik memberi impak yang besar terhadap penghutang berbanding melalui kaedah penulisan dan kesaksian di mana kedua-dua kaedah ini boleh dimanipulasi dengan mudah seterusnya menafikan hak pemiutang. Pembentukan akad cagaran yang mewujudkan hak pengikat dan hak memegang harta cagaran tidak ada dalam kaedah pendokumentasian dan kesaksian. Hak-hak ini tidak boleh disangkal oleh kedua-dua belah pihak tanpa persetujuan antara satu sama lain. Kesannya kedua-dua pihak berkepentingan mampu untuk berurusan dengan lebih selamat dan terjamin terhadap harta masing-masing.

Dalam konteks semasa, akad cagaran sering digunakan dalam institusi perbankan bagi memudahkan urusan pinjaman di samping mengatasi masalah yang mungkin timbul sekiranya penghutang tidak dapat melunaskan hutang atau melakukan salah laku. Ia boleh digambarkan sebagai instrumen untuk mengikat dan menjamin pulangan bayaran balik wang pinjaman. Sebagai contoh apabila seseorang ingin mendapatkan wang melalui pinjaman sama ada menerusi individu mahupun institusi kewangan, pihak pemiutang meletakkan syarat supaya penghutang menjadikan sesuatu barang yang bernilai seperti emas untuk dijadikan cagaran dan disimpan oleh pemiutang secara wadi'ah atau amanah sehinggalah hutang dilunaskan sepenuhnya (Asmadi 2004).

Kandungan dan tujuan utama pensyariatan akad cagaran adalah untuk memastikan jaminan hutang pemiutang di samping membantu masyarakat mendapatkan kredit dengan lebih mudah sama ada melalui pinjaman, bayaran tertunda, salam dan istisna' (Uzaimah \& Safinar 2006). Pembentukan akad cagaran ke atas sesebuah harta tidak mengeluarkan harta daripada pemilikan pemilik yang asal. Namun, ia menghadkan transaksi yang boleh dilakukan oleh keduadua pihak sama ada pencagar atau pemegang cagaran yang mempunyai kepentingan masingmasing terhadap harta. Dengan kata lain pemilik tidak lagi memiliki harta secara sempurna yang membolehkannya melakukan sebarang transaksi sebagaimana kebebasan yang dimiliki sebelum cagaran terbentuk. Hal ini kerana syarak menjaga kepentingan dan hak pemberi pinjaman iaitu untuk mendapatkan balik hutangnya sekiranya penghutang tidak mampu untuk membayar balik hutang pinjaman.

Manakala konsep hibah pula adalah pemberian milik harta semasa hayat seseorang kepada individu lain tanpa apa-apa balasan yang dibuat secara sukarela (Noor Lizza et al. 2012). 
Berbeza dengan bentuk pemberian secara sukerala yang lain seperti wasiat, hibah berkuatkuasa semasa hayat pemberi dan ia tidak dikaitkan dengan kematian mana-mana pihak bagi membolehkan pemilikan berkuat kuasa secara sah. Pemberian hibah juga tidak terikat dengan kadar dan individu tertentu. Hibah boleh diberikan kepada sesiapa yang dikehendaki muslim atau tidak dan tiada had tertentu sebagaimana konsep wasiat.

\section{Hibah Harta Bercagar Menurut Pandangan Fuqaha dan Kes-kes di Mahkamah Syariah}

Pemilikan sempurna merupakan antara syarat utama harta hibah bagi membolehkan hibah berkuat kuasa secara sah. Selain daripada harta mestilah bernilai menurut syarak, wujud ketika hibah berlangsung dan ditentukan, harta juga mestilah dimiliki secara sempurna oleh pemberi hibah ketika akad hibah dibuat. Milik sempurna bererti seseorang memiliki fizikal dan manfaat harta pada masa yang sama (Mohd Zamro et al. 2010). Seseorang tidak dikatakan memiliki harta secara sempurna jika ia hanya memiliki salah satu daripada manfaat atau fizikal sahaja seperti pemilikan seorang penyewa terhadap barang yang disewa.

Dalam isu hibah harta bercagar, umumnya harta yang dicagar mestilah milik sempurna pencagar berdasarkan kaedah menyebut setiap barang yang sah dijual beli sah untuk dicagar (alSuyuti 2013). Oleh kerana itu hak pemilikan pencagar masih kekal meskipun harta tersebut dijadikan cagaran sehinggalah hutang dilunaskan sepenuhnya. Namun, dalam situasi ini apabila akad cagaran terlaksana, secara tidak langsung hak pemegang cagaran telah terbentuk iaitu sebagai pengikat hutang dan jaminan pulangan bayaran balik hutang (al-Sharbini 2009). Justeru, pencagar tidak lagi mempunyai akses penuh ke atas hartanya sebagaimana kebebasan yang dimilikinya sebelum akad cagaran terbentuk. Begitu juga bagi pihak pemegang cagaran, meskipun harta tersebut berada dalam jagaannya tidak bermakna pemegang mempunyai kebebasan untuk melakukan transaksi ke atas harta selagi tempoh bayaran balik belum tamat. Meskipun demikian, para fuqaha membahaskan isu ini bagi menjaga kepentingan kedua-dua belah pihak berakad.

Ringkasnya, pendapat para fuqaha berkaitan isu ini terbahagi kepada dua pendapat. Pendapat pertama dipelopori oleh mazhab Shafi'i dan Hanbali mengatakan bentuk tasarruf terhadap harta cagaran yang boleh menggugurkan hak pemilikan tanpa ada pertukaran dan berlaku perpindahan pemilikan adalah terbatal jika sekiranya dilakukan tanpa keizinan pemegang cagaran seperti jual beli, hibah dan wakaf (al-Ramly 1996; al-Nawawi 2012). Ini kerana sekiranya tasarruf tersebut sah, maka hak pengikat (al-wathiqah) dan kepentingan pemegang cagaran akan tergugat. Sekiranya pemegang cagaran memberi keizinan untuk menghibahkan atau mewakafkan harta cagaran, tasarruf tersebut adalah sah namun akad cagaran terbatal (al-Sharbini 2009). Keizinan tersebut hendaklah diberikan semasa tasarruf dibuat. Bentuk-bentuk tasarruf tersebut termasuk dalam perkara-perkara yang membatalkan akad cagaran meskipun dibuat dengan izin pemegang cagaran (al-Wizarah al-Awqaf 2002).

Pendapat ini diterima pakai dalam kes Sabedah binti Abdullah lwn. Tiga yang lain (05100044-0082-2007) yang dibicarakan di Mahkamah Tinggi Syariah Seremban, mahkamah menolak permohonan pengesahan hibah plaintif apabila mendapati salah satu rukun hibah tidak dipatuhi. Plaintif dalam kes ini mendakwa arwah orang tuanya Gedek binti Durin telah menghibahkan beberapa bidang tanah semasa hidup kepada beliau. Walau bagaimanapun semasa hibah dibuat salah satu daripada tanah-tanah terbabit masih dalam tempoh bayaran balik kepada pihak Felda. Oleh yang demikian, mahkamah memutuskan hibah yang dibuat adalah tidak sah dengan alasan tanah tersebut masih bukan milik sempurna pemberi hibah ketika hibah dilakukan.

Alasan hakim dalam kes ini bertepatan dengan pendapat golongan pertama iaitu harta mestilah milik penuh pemberi hibah. Keizinan pemegang cagaran tidak akan menjadikan hibah berkenaan sah. Hakim dalam kes ini tidak menyentuh isu berkaitan kewujudan bentuk-bentuk keizinan yang mungkin ada menunjukkan pendapat mazhab Shafi'i digunai pakai.

Manakala pendapat kedua dalam kalangan fuqaha mazhab Hanafi dan Maliki mengatakan transaksi pencagar terhadap harta cagaran termasuklah hibah adalah terhenti (mawquf) sehinggalah mendapat keizinan pemegang cagaran (al-Zuhayli 2014). Perkataan mawquf 
memberi maksud bahawa hibah tidak terus terbatal dan ia masih boleh menjadi sah pada masa akan datang dengan terjadinya beberapa perkara iaitu mendapat keizinan pemegang cagaran atau harta telah menjadi milik sempurna pemberi hibah. Selama dalam tempoh berkenaan, segala hak pemilikan dan hak-hak penerima hibah adalah terhenti sehinggalah keizinan pemegang cagaran diperoleh atau harta tersebut menjadi miliknya secara sempurna. Keizinan tersebut boleh didapatkan semasa atau selepas akad dibuat.

Golongan ini berhujah mengatakan tasarruf pencagar seperti jual beli, hibah, sewa, sedekah, iqrar dan kitābah merupakan tasarruf yang boleh difasakhkan tetapi hak untuk menfasakhkannya bukan milik pemegang cagaran. Hal ini kerana tasarruf tersebut dibuat oleh pencagar yang mempunyai kelayakan dan wilayah ke atas harta. Di samping itu, tasarruf ini tidak menafikan hak memegang (al-mahbus) pemegang cagaran (Ibn 'Abidin 1992: 509). Dengan erti kata lain hak untuk memegang harta cagaran masih kekal meskipun harta dihibah atau dijual. Oleh yang demikian, hibah tersebut tidak terus membatalkan akad cagaran tetapi hanya memerlukan keizinan daripada pemegang cagaran untuk melaksanakannya (yanfadh) sebagaimana dalam permasalahan membebaskan harta cagaran yang berbentuk hamba (Ibn 'Abidin 1992).

Pendapat ini diguna pakai oleh pemerintahan Islam terdahulu sebagaimana yang diperuntukkan dalam Majallah al-Ahkam al-Adliyyah perkara 857:

\begin{abstract}
"Jika seseorang menghibahkan harta orang lain tanpa keizinan daripada pemilik harta, hibah adalah tidak sah. Namun, sekiranya selepas pemberian dibuat pemilik harta berkenaan membenarkan pemberian tersebut, maka hibah menjadi sah kerana kebenaran yang dilakukan selepas itu sama seperti dengan perwakilan yang dibuat sebelum daripada hibah tersebut".
\end{abstract}

Pendapat ini turut diaplikasikan dalam undang-undang sivil Syria, Mesir dan Jordan yang tidak mengharuskan hibah harta milik orang lain melainkan dengan keizinan atau persetujuan daripada pemilik harta yang sebenar dan kesahan akad hibah bergantung kepada kebenaran yang diberikan oleh pemilik harta (Noor Lizza et al. 2012).

Melihat kepada amalan dan adat masyarakat Islam setempat yang majoritinya memiliki harta menerusi pembiayaan pinjaman bank, pendapat mazhab Hanafi adalah amat sesuai untuk diguna pakai. Bahkan keadaan ini dilihat bakal berterusan untuk tempoh jangka masa yang panjang ditambah pula dengan inisiatif-inisiatif kerajaan yang membantu masyarakat mendapatkan aset seperti rumah dengan lebih mudah. Sekiranya hibah harta bercagar tidak dibenarkan ia bukan sahaja memberikan kesulitan kepada masyarakat bahkan impak negatif kepada ekonomi negara kesan daripada kegagalan perancangan harta yang baik. Berdasarkan kaedah fiqh yang menyebut:

Maksudnya:

$$
\text { إذا ضاق الأمر اتسع }
$$

Apabila sesuatu perkara menjadi sulit, maka syarak memberi keluasan.

Oleh yang demikian, penggubalan undang-undang hibah pada masa akan datang perlu mengambil kira keadaan dan maslahah masyarakat pada hari ini terutama melibatkan aset yang mempunyai nilai yang tinggi.

Dalam konteks perundangan syariah di Malaysia, oleh kerana Mahkamah Syariah tidak mengamalkan konsep doktrin duluan mengikat dan masih belum ada akta khusus yang digubal berkaitan hibah, Hakim-hakim Syarie bebas memilih pendapat fuqaha yang sesuai berdasarkan justifikasi seorang hakim. Pendapat kedua ini diterima pakai oleh Hakim Syarie dalam kes Shahirah Aimi binti Shahrudin v Siti Hawa binti Abu Talib dan Shamimi Aqilah binti Shaharudin (05000-044-0002-2014) yang dibicarakan di Mahkamah Rayuan Seremban. Plaintif dalam kes ini telah tidak berpuas hati dengan keputusan Mahkamah Tinggi Seremban kerana tidak mengesahkan hibah berbentuk harta tak alih iaitu sebuah rumah yang dibuat kepada beliau. Dalam perbicaraan di Mahkamah Tinggi, Hakim Syarie mendapati harta yang dihibah iaitu rumah 
tersebut masih dalam hutang pinjaman pihak Maybank ketika hibah dibuat melalui kontrak Bay' bi Thaman 'Ajil (BBA) dan dijangka tamat pada tahun 2017.

Oleh yang demikian, mahkamah memutuskan hibah tersebut tidak sah kerana pemberi hibah masih tidak memiliki harta tersebut secara sempurna ketika ia dibuat. Penghujahan hakim dalam Mahkamah Tinggi bersandarkan pendapat fuqaha yang tidak membenarkan hibah bercagar sebagaimana yang disebutkan oleh Hakim Syarie:

\begin{abstract}
“Pemilikan sempurna hanya berlaku selepas kematian iaitu dengan bayaran penuh oleh pihak takaful. Seorang pemberi hibah mestilah mempunyai kuasa mutlak dan dalam kes ini hibah dibuat ke atas rumah yang masih terikat dengan kontrak pinjaman pihak bank. Oleh yang demikian, Mahkamah mendapati bahawa pemilikan si mati terhadap rumah tersebut semasa hidup dan semasa hibah dibuat ialah pemilikan tidak sempurna. Justeru si mati tidak boleh menyerahkan rumah tersebut kepada mana-mana pihak sehingga pembayaran kepada dibuat sepenuhnya."
\end{abstract}

Daripada penghujahan hakim Mahkamah Tinggi, dapat dilihat bahawa hakim tidak menyentuh sama ada hibah yang dibuat mendapat keizinan daripada pihak pemegang cagaran atau tidak. Kenyataan hakim tentang pemilikan sempurna pemberi hibah yang hanya berlaku selepas kematian pemberi adalah selari dengan pendapat fuqaha Shafi'i. Transaksi hibah yang berlaku tanpa keizinan pemilik harta atau ke atas harta cagaran adalah terbatal dan tidak boleh ditangguh ke masa akan datang.

Berbeza apabila kes ini dirayu ke Mahkamah Rayuan. Mahkamah Bicara memutuskan hibah si mati kepada perayu adalah sah dan membatalkan keputusan Mahkamah Tinggi. Alasan penghakiman Hakim Bicara adalah perayu telah mendapatkan keizinan daripada pihak pemegang cagaran iaitu pihak Maybank untuk menghibahkan rumah tersebut:

\begin{abstract}
"Walaupun si mati telah meninggal dunia pada 14 Disember 2009, perjanjian tersebut masih mengikat sesiapa yang menggantikan si mati terhadap rumah tersebut. Dalam kes ini perayu adalah pengganti si mati dan telah bertindak sebagai orang yang dihibahkan rumah tersebut kepadanya. Perayu telah berurusan dengan pihak bank bagi menyelesaikan hutang yang tertunggak. Sebagai pemegang cagaran pihak bank mempunyai kuasa untuk membatalkan hibah yang dibuat oleh si mati berdasarkan konsep قابلة للإبطال akan tetapi pihak bank tidak berbuat demikian tetapi menerima RM50,000 daripada perayu untuk melunaskan hutang. Tindakan bank tersebut secara tidak langsung adalah bentuk pengiktirafan kepada kedudukan perayu yang mengambil alih bebanan dan liabiliti rumah tersebut. Tidak terdapat keterangan bank yang cuba mengambil alih rumah tersebut dan membatalkan hibah yang dibuat. Oleh yang demikian secara tidak langsung pihak bank membenarkan hibah yang dibuat oleh si mati."
\end{abstract}

Berdasarkan penghujahan di atas, Hakim Bicara menerima tindakan perayu yang menyelesaikan baki hutang dan penerimaan bayaran baki hutang oleh pihak bank sebagai bentuk keizinan meskipun tidak berlaku sebarang pindah milik. Ini membuktikan bentuk keizinan bukanlah suatu yang sempit (rigid) bahkan ia boleh diperluaskan dalam pelbagai bentuk bergantung kepada uruf dan adat masyarakat setempat. Selain itu, pihak bank sebagai pemegang cagaran boleh membatalkan hibah yang dibuat tanpa pengetahuan dan keizinannya berdasarkan pendapat jumhur fuqaha tetapi tidak berbuat demikian. Situasi ini jelas menunjukkan pihak bank selaku pemegang cagaran membenarkan hibah dengan syarat baki hutang mestilah dilunaskan sama ada melalui takaful atau sebagainya.

Dalam alasan penghakiman oleh Hakim Bicara, penulis bersetuju bahawa kedudukan perayu sebagai orang yang mengambil alih bebanan dan liabiliti diiktiraf sebagai keizinan pemegang cagaran sebagaimana yang ditetapkan dalam polisi pihak bank: "this agreement shall be binding upon the successors in-tittle personal representive, heirs and assigns, as case may be of the parties here to".

Oleh yang demikian, sekiranya penerima hibah menggantikan tempat pemberi hibah sebagai personal representive dengan menanggung hutang dan bebanan harta, pihak bank tidak 
akan menafikan hibah yang dibuat kerana mereka masih menerima bayaran balik wang pinjaman. Secara tidak langsung ia boleh dianggap sebagai satu bentuk pengiktirafan oleh pihak bank membenarkan harta dihibah. Hal ini juga kerana pihak bank tidak mengambil tahu tentang kedudukan harta berkenaan selagi bayaran balik hutang kepada mereka dibayar. Meskipun jika diteliti dalam soal jawab antara Hakim Bicara dan pegawai Maybank sebagai saksi dalam kes ini, pihak bank masih belum mengamalkan polisi membenarkan harta cagaran dihibah, ia masih boleh dihibah dengan adanya bentuk-bentuk keizinan seperti yang berlaku dalam kes ini.

Isu penting yang turut perlu diberi perhatian dalam kes ini adalah personal representive, kedudukan penerima sebagai wakil persendirian bukan hanya menjadi keizinan pihak bank bahkan ia menjadi liabiliti baharu yang perlu ditanggung oleh penerima dengan melunaskan bayaran bulanan seperti biasa. Dengan kata lain, pindah milik yang berlaku adalah sama ada dengan persetujuan untuk sambung bayar atau penerima membuat pinjaman baharu ke atas harta berkenaan. Ini dapat dibuktikan dengan kenyataan pihak bank dalam penghujahan di atas bahawa perjanjian yang dibuat antara pembeli dan pembiaya akan mengikat sesiapa yang menggantikan tempat pembeli yang asal.

Justeru, penulis bersetuju dengan pendapat Hakim Bicara bahawa ia boleh dianggap sebagai bentuk keizinan meskipun tidak dinyatakan secara jelas. Kedudukan hibah dalam konteks sebegini adalah berdasarkan pendapat mazhab Hanafi yang membenarkan harta cagaran dihibah meskipun keizinan daripada pemegang cagaran diperolehi selepas akad dibuat.

Melihat kepada kes terbaru yang diputuskan di Mahkamah Syariah Seremban di atas, hibah harta bercagar boleh dilaksanakan dan diterima oleh Mahkamah Syariah sekiranya hibah dibuat dengan keizinan pihak pemegang cagaran dan harta dilindungi oleh polisi takaful. Kewujudan elemen takaful memberi impak yang besar terhadap keputusan yang bakal dibuat oleh Mahkamah Syariah. Permasalahan harta bukan milik sempurna pemberi hibah boleh diatasi dengan adanya polisi takaful. Berdasarkan pendapat fuqaha Hanafi hibah harta yang masih orang lain adalah mawquf sehinggalah mendapat kebenaran pemilik atau harta menjadi miliknya pada masa akan datang. Justeru penulis berpendapat, tidak timbul isu kesahan hibah harta bercagar kerana takaful yang diambil oleh pembeli sudah menjamin perkara tersebut.

Selain itu, impak daripada keputusan dalam kes ini memberikan perspektif bahawa pelaksanaan hibah harta bercagar sudah mula diterima di institusi kehakiman Islam. Ini membuktikkan kajian yang dilakukan oleh Wan Kamal Mujani et.al (2012) sudah terjawab. Kajian mereka menyatakan pada ketika itu hibah harta bercagar tidak boleh dilaksanakan kerana terdapat beberapa kekangan undang-undang termasuklah apabila melibatkan pertikaian di Mahkamah Syariah. Hal ini berdasarkan beberapa kes yang telah diputuskan tidak sah seperti Awang bin Abdul Rahman lwn. Shamsuddin bin Awang \& Lain-lain [1998] 6 MLJ 231. Justeru, implimentasi hibah harta cagaran boleh diamalkan tetapi hendaklah dikawal oleh badan yang berautoriti supaya tiada pihak yang cuba mengambil kesempatan terhadap pelaksanaannya.

Dalam perundangan sivil, kes Eng Ah Mooi \& Ors. v. Oversea Chinese Banking Corporation Ltd. [1983] 1 MLJ 209, Mahkamah Persekutuan membenarkan penggadai menjual harta gadaian atau dengan erti kata lain memindah milik harta gadaian kepada penerima milik yang baharu kerana beliau telah gagal membayar bayaran hutang kepada pemegang gadaian. Dalam kes ini bagi tujuan menutup malu, penggadai telah menjual tanah tersebut kepada perayu sebelum perintah jualan dikeluarkan oleh pihak mahkamah. Pihak penggadai berbuat demikian berdasarkan persetujuan yang telah disepakati bersama dengan perayu bahawa wang hasil daripada jualan tersebut akan diserahkan kepada pihak pemegang gadaian untuk melepaskan bebanan cagaran. Selepas urusan jual beli, perayu telah menyerahkan wang tersebut kepada pihak pemegang cagaran sebagai usaha untuk melepaskan bebanan cagaran harta tersebut.

Pihak bank walau bagaimanapun menolak pembayaran tersebut dengan alasan bahawa perjanjian yang dibuat di antara penggadai dan perayu merupakan satu fraud atau penipuan terhadap mereka. Disebabkan itu, perayu telah membuat permohonan kepada mahkamah bahawa gadaian terhadap tanah tersebut berhak dilepaskan kerana segala hutang yang terkumpul telah dibayar sepenuhnya. Hakim Mahkamah Persekutuan Salleh Abas tidak bersetuju terhadap keputusan Hakim Bicara dan memutuskan selama hak dan kepentingan pihak 
pemegang cagaran terjamin iaitu menerima balik pembayaran hutang yang terkumpul perjanjian tersebut adalah sah. Sebaliknya jika kepentingan pihak pemegang cagaran terabai, pihak pemegang cagaran berhak untuk mengekalkan gadaian dan menolak proses pelepasan gadaian. Dalam kes ini Mahkamah Persekutuan berhujah:

\begin{abstract}
"the fact that the chargor sells his charged property even for a price less than the amount of secured debt or for a nominal sum of one dollar or makes a free gift to a third party is no concern of the chargee so long as he would be protected to receive in full the debt due to him. Suppose a chargor make a free gift of the charged land to his son, who subsequently tenders the full amount of debt to the chargee demanding a discharge of the charge, could be the free gift described as a fraud so as to entitle the chargee to refuse to release the charge? The answer must be in negative. As long as the law recognises the right of a chargor to transfer the charged property (see section 214, and 215 of the National Land Code), the sale or the gift of the charged property cannot amount to a fraud, even if such sale or gift effected with a view to preventing the chargee from selling the property, provided, of course, his right remains fully protected"
\end{abstract}

Penghakiman dalam kes ini jelas menunjukkan pindah milik harta yang masih dalam gadaian adalah terhalang disebabkan oleh kepentingan harta yang dijadikan sekuriti kepada pihak bank. Sekiranya kepentingan tersebut mampu dijamin seperti dalam kes ini maka pindah milik boleh dilaksanakan. Dalam kenyataan awal Mahkamah Persekutuan, pemegang gadaian tidak berhak untuk mempersoalkan tindakan penggadai menjual atau menghibahkan harta gadaian selagi kepentingan pihak pemegang cagaran dilindungi untuk menerima sepenuhnya baki hutang pinjaman. Sekiranya seorang ayah ingin menghibahkan hartanya yang masih dalam gadaian kepada anaknya perkara pertama yang perlu diambil perhatian adalah jaminan bayaran balik sepenuhnya hutang serta keizinan daripada pemegang gadaian. Undang-undang boleh mengesahkan urusan pindah milik dilakukan dan bebanan harta dilepaskan sekiranya kepentingan tersebut terjamin.

Senario yang berlaku dalam kes di atas sama seperti dalam konteks hibah harta bercagar. Harta yang dilindungi oleh takaful akan dibayar sepenuhnya dengan pampasan takaful apabila terjadi musibah atau kematian kepada pembeli atau pemberi hibah. Kepentingan pemegang cagaran sudah terjamin dan harta boleh dipindah milik selepas dibayar sepenuhnya oleh polisi takaful. Oleh itu, dalam perundangan sivil isu kepentingan pemegang cagaran boleh di atasi dengan kewujudan takaful.

Selain itu, isu yang timbul ini juga berpunca daripada syarat qabd yang ditetapkan jumhur fuqaha bagi membolehkan hibah berkuat kuasa secara sah dan mengikat di sisi undang-undang. Dalam perundangan Islam qabd atau penerimaan harta hibah boleh dilakukan dalam pelbagai bentuk dan tidak disyaratkan berlakunya pertukaran nama atau perpindahan milik dalam dokumen. Ini bermakna hibah telah dianggap sempurna sekiranya segala rukun dan syarat telah dipenuhi termasuklah diserahkan kepada penerima seperti menyerahkan kunci, mengosongkan bangunan dan seumpamanya. Isu yang tinggal adalah pindah milik nama ke atas penerima hibah yang hanya boleh dilakukan setelah hutang rumah dilunaskan sepenuhnya.

\title{
Isu dan Halangan Produk Hibah Harta Bercagar
}

Sudah menjadi kebiasaan amalan pihak bank mencagarkan aset atau harta yang dibeli melalui pembiayaan pinjaman (Resolusi Syariah Bank Negara Malaysia 2010). Hal ini bertujuan untuk melindungi hak mereka selaku pemegang cagaran dan pembiaya sekiranya pelanggan (penghutang) tidak mampu untuk melunaskan hutang dalam tempoh yang dipersetujui. Oleh yang demikian, selama dalam tempoh berkenaan seseorang pembeli tidak mempunyai hak untuk melakukan transaksi pindah milik ke atas harta tanpa kebenaran daripada pihak bank dan sebarang pemindahan ke atas harta sepanjang tempoh berkenaan adalah terbatal (Wan Kamal Mujani et al. 2012). 
Sehingga hari ini masih belum ada mana-mana institusi kewangan seperti bank mengamalkan polisi membenarkan harta yang masih dalam cagaran dihibah atau dipindah milik. Kesediaan pihak bank untuk mengubah polisi yang membenarkan hibah harta bercagar adalah agak mustahil jika dilihat amalan semasa. Hal ini kerana bank tidak sanggup untuk menanggung sebarang risiko yang mungkin timbul sekiranya harta dipindah milik melalui hibah. Bahkan sekiranya ia berlaku tanpa pengetahuan pihak bank, bank boleh melakukan remedi jualan harta untuk mendapatkan bayaran balik hutang pinjaman (Wan Kamal Mujani et al. 2012).

Bagi pihak yang menerima pakai hibah harta bercagar ianya dihujahkan bahawa kepentingan tersebut tidak akan tergugat meskipun harta cagaran dihibah kerana ia dilindungi oleh polisi takaful. Polisi takaful yang diambil oleh pembeli sama ada Mortgage Reducing Term Takaful (MRTT) atau Mortgage Level Term Takaful (MLTT) akan membayar pampasan dan jaminan penuh terhadap hutang pinjaman sekiranya berlaku sebarang musibah atau kematian kepada pembeli. Dengan erti kata lain, kepentingan pihak bank adalah terjamin meskipun harta dihibah. Jika dilihat dari satu sudut, takaful memainkan peranan penting dalam merealisasikan pelaksanaan produk ini. Kewujudan elemen takaful juga memberi impak yang besar terhadap keputusan Mahkamah Syariah berkaitan kes hibah harta bercagar seperti yang berlaku dalam kes-kes di atas.

Walau bagaimanapun, terdapat beberapa kelemahan dalam polisi takaful yang perlu diberi perhatian seperti kes pelanggan yang meletakkan dua nama dalam satu polisi (Naziree 2011). Apabila berlaku kematian pampasan hanya akan diberi separuh daripada jumlah baki hutang yang berbaki dan selebihnya masih perlu dibayar seperti biasa oleh penama kedua. Kesannya pihak bank tidak akan melepaskan bebanan ke atas harta tersebut seterusnya menghalang ia dipindah milik melalui hibah. Begitu juga baki kes sekiranya pelanggan diisytihar muflis.

Sekiranya harta berkait dengan tanah, maka ia hendaklah mengikuti perundangan yang telah ditetapkan dalam Kanun Tanah Negara 1965 (KTN). Berdasarkan KTN 1965 bebanan terhadap sesebuah tanah seperti gadaian hanya akan dilepaskan setelah hutang dilunaskan sepenuhnya. Hal ini sebagaimana menurut Farahwaheda (2015) menyatakan bagi hartanah yang melibatkan hak kepentingan pemegang gadaian atau hartanah yang masih dalam hutang pihak bank, urusan pendaftaran pindah milik hanya akan dilakukan setelah tiada surat bantahan daripada pemegang gadaian diperolehi. Selagi pihak bank atau pemegang gadaian tidak memberikan kelulusan untuk memindah milik hartanah cagaran, pejabat tanah tidak akan melakukan sebarang urusan pendaftaran pindah milik (Farahwaheda 2015). Hal ini jelas menunjukkan kepentingan pihak ketiga iaitu bank terhadap harta cagaran menghalang harta tersebut dipindah milik sama ada melalui hibah atau selainnya.

Sebagaimana dalam kes Lim Chuan Eng Sdn. Bhd.v. United Malayan Banking Corporation \& Anor [2010] 9 CLJ 637 yang dibicarakan di Mahkamah Rayuan Putrajaya salah seorang panel hakim menegaskan peruntukan-peruntukan Kanun Tanah Negara 1965 mengenai gadaian adalah untuk melindungi penggadai atau pemilik tanah. Oleh itu, penggadai dan pemegang gadaian tidak boleh melakukan sebarang bentuk urus niaga ke atas tanah yang digadai melebihi peruntukan yang telah ditetapkan dalam Kanun Tanah Negara 1965. Bagi pihak pemegang gadaian urusan jualan tanah apabila pembeli gagal membayar hutang hendaklah dilaksanakan berdasarkan jualan kehakiman iaitu mendapatkan perintah jualan daripada pihak mahkamah terlebih dahulu bagi membolehkan urus niaga tersebut diiktiraf di sisi undang-undang. Namun, penggadai juga boleh melakukan urus niaga tersebut dengan keizinan pemegang gadaian kerana jualan sebegitu tidak perlu menjadi suatu jualan kehakiman di bawah Kanun Tanah Negara.

Walau bagaimanapun, terdapat klausa dalam Kanun Tanah Negara 1965 yang membenarkan harta yang masih dalam cagaran dipindah milik. Namun, segala bebanan termasuklah liabiliti, pajakan, gadaian dan lain-lain hendaklah turut berpindah kepada penerima milik yang baru seperti yang berlaku dalam kes Shahirah Aimi binti Shahrudin v Siti Hawa binti Abu Talib dan Shamimi Aqilah binti Shaharudin (05000-044-0002-2014). Dengan kata lain, penerima pindah milik perlu menanggung dan menjelaskan segala bebanan ke atas tanah tersebut termasuklah hutang yang masih berbaki barulah pindah milik boleh dilakukan. Seksyen 
215 (3) Kanun Tanah Negara 1965 menyebutkan: "Penerima pindah milik mana-mana tanah beri milik hendaklah memegang tanah beri milik tertakluk kepada":

Apa-apa pajakan, gadaian, atau kepentingan berdaftar yang sedia ada mengenainya pada masa pindah milik itu didaftarkan.

Berdasarkan peruntukkan ini, harta yang masih dalam cagaran boleh dipindah milik melalui hibah dengan syarat segala bebanan harta mestilah ditanggung oleh bakal penerima hibah. Namun, perkara ini lazimnya perlu dilakukan dengan keizinan pihak pemegang cagaran (Salleh Buang 1993) dan realiti yang berlaku pada hari ini adalah bank selaku pemegang cagaran masih belum bersedia untuk berbuat sedemikian.

Nasrul Hisyam (2011) mengatakan pembeli masih boleh melakukan hibah dengan syarat penerima perlu melakukan proses pinjaman baharu dan mengambil kira harga pasaran semasa. Kaedah ini mengguna pakai konsep hibah bersyarat. Hibah bersyarat dibolehkan oleh sebahagian fuqaha selama syarat yang diletakkan tidak menafikan tujuan asal pemberian hibah dan tidak merugikan pihak penerima hibah. Namun, sejauh manakah syarak membenarkan syarat balasan seperti yang dicadangkan kerana ia seolah-olah berlaku pertukaran antara pemberi dan penerima meskipun lafaz yang digunakan adalah lafaz hibah. Kaedah fiqh menyebutkan "apa yang diambil kira dalam muamalat adalah makna yang tersirat bukan pada lafaz". Isu pertukaran milik di dalam dokumen bukanlah menafikan hibah yang dibuat. Ini kerana syarak tidak menetapkan qabd mestilah berlaku dengan pertukaran milik nama bahkan boleh dilakukan dengan apa-apa tindakan yang diiktiraf oleh masyarakat seperti menyerahkan kunci, mengosongkan bangunan dan seumpamanya.

Kesimpulannya, hibah harta bercagar sememangnya boleh dijadikan instrumen pengurusan harta yang berkesan terutama bagi harta tak alih seperti rumah dan hartanah. Hibah harta bercagar mengguna pakai dua konsep utama dalam Islam iaitu cagaran dan hibah. Para fuqaha berselisih pendapat mengenai keharusan menghibah harta yang masih dalam cagaran kerana kedudukan harta tersebut sebagai jaminan bayaran balik pinjaman.

Berdasarkan pendapat mazhab Hanafi harta yang masih dalam cagaran boleh dihibahkan dengan syarat mendapat keizinan daripada pemegang cagaran. Sekiranya hibah dilakukan terlebih dahulu tanpa pengetahuan pemegang cagaran transaksi tersebut tidak terus terbatal tetapi terhenti sehinggalah keizinan diperolehi atau harta menjadi milik sempurna pemberi. Pendapat ini telah diguna dalam kes terbaru yang telah diputuskan di Mahkamah Syariah dan Hakim Syarie menerima konsep hibah bercagar dilaksanakan dengan syarat adanya bentukbentuk keizinan meskipun tidak dinyatakan secara jelas seperti kewujudan pampasan takaful. Keputusan dalam kes ini memberikan perspektif bahawa hibah harta bercagar telah mula diterima di Mahkamah Syariah dan ia adalah tidak mustahil untuk dilaksanakan. Bahkan jika dilihat kepada amalan semasa kes-kes seperti ini akan lebih banyak berlaku pada masa akan datang.

Beberapa kekangan dikenal pasti seperti keizinan daripada pemegang cagaran iaitu pihak bank yang masih belum membenarkan harta yang dicagar kepada mereka dipindah milik melalui hibah atau selainnya. Masih belum ada mana-mana polisi bank yang membenarkan harta cagaran dihibah kerana ia boleh mengundang pelbagai risiko pada masa akan datang. Berdasarkan Kanun Tanah Negara 1960 harta yang mempunyai bebanan termasuklah dicagar tidak boleh dipindah milik melainkan bebanan tersebut telah dilepaskan seperti hutang dibayar sepenuhnya. Kewujudan elemen takaful boleh dimanfaatkan untuk mengatasi masalah ini kerana bebanan ke atas harta boleh dilepaskan setelah pembeli menerima bayaran pampasan takaful. Penyelesaian di antara dua entiti iaitu penyedia dokumen hibah dan pihak pemegang cagaran perlu dilakukan supaya pelaksanaan produk hibah harta bercagar lebih diyakini dan sistematik. 


\section{References}

Akmal Hidayah Halim, \& Tajul Aris Ahmad Bustami. 2017. Pelaksanaan hibah amanah sebagai satu instrumen pengurusan harta di Malaysia. Jurnal Kanun. 29 (2): 90-115.

Alias Azhar, Mohammad Azzam Hussain, Muhammad Hafiz Badarulzaman \& Fauziah Mohd Nor. 2014. Hibah Komersial: Satu Tinjauan Terhadap Prosedur Dan Amalan di Malaysia. Pulau Pinang: Universiti Sains Islam Malaysia.

Asmadi Mohamed Naim. 2004. Sistem gadaian dalam Islam. Islämiyyat 26(2): 39-57.

Bernama. 2018. Skim pinjaman perumahan bantu M40, B40 miliki rumah. 3 Julai.

Farahwaheda binti Abdul Rahman. 2015. Isu hibah hartanah dan aplikasi terhadap Kanun Tanah Negara1965. Disertasi Sarjana Pengajian Islam, Jabatan Syariah, Universiti Kebangsaan Malaysia.

Frederik van Tuyll. 2006. The emergence of the Islamic trust. Trust \& Trustee Oxford Academic Journal. 12 (9): 7-9. doi: https://doi.org/10.1093/tandt/ttl009.

Al-Hisny, Taqiy al-Din Abu Bakr bin Muhammad al-Husainy. 2013. Kifayah al-Akhyar fi hall Ghayah al-Ikhtisar. Dimashq: Dar al-Faiha'.

Ian Edge. 2008. Methods of avoidance of the fixed heirship rules in Islamic Law: the Islamic Trust. Trust \& Trustee Oxford Academic Journal. 14 (7): 457-456. doi: https://doi.org/10.1093/tandt/ttn069.

Ibnu 'Abidin, Muhammad Amin bin 'Umar bin 'Abdul al-'Aziz. 1992. Al-Dur al-Mukhtar wa Hasyiah Ibn 'Abidin. Jil 6. Beirut: Dar al-Fikr.

Krippendorff, K. 1980. Content Analysis: An Introduction to Its Methodology. Newbury: Sage Publication.

Mohd Zamro Muda, Azlin Alisa Ahmad \& Salmy Edawati Yaacob. 2010. Konsep pemilikan harta dalam Islam: satu tinjauan umum. Isu-isu harta orang Islam. Bangi. Penerbit: Universiti Kebangsaan Malaysia.

Nasrul Hisyam Nor Muhamad. 2011. Penyelesaian pindah milik harta bercagar di institusi kewangan: dari perspektif undang-undang Islam. Kanun 23(2): 180-193.

Nasrul Hisyam Nor Muhamad, Ahmad Che Yaacob \& Norazila Che Hussain. 2017. Konsep hibah bersyarat dan aplikasinya dalam perancangan harta. UMRAN-International Journal of Islamic and Civizilation Studies. 3 (3-1): 32-41.

Naziree Md. Yusof. 2011. Takaful bertempoh gadai janji berkurangan: masalah dan persoalan. KANUN: Jurnal Undang-undang. 23 (1): 21-39.

Al-Nawawi, Abi Zakaria Yahya bin Syaraf. 2012. Raudhah al-Thalibin. Jil 4-5. Dimashq: Dar alFaiha'.

Noor Lizza Mohamed Said, Mohd Ridzuan Awang, \& Amir Husin Mohd Nor. 2012. Hibah dengan syarat balasan menurut pandangan fuqaha dan kedudukannya dalam undang-undang $\begin{array}{lllll}\text { sivil Jordan. } & \text { Jurnal } & \text { Syariah. } & 20 & \text { (3): }\end{array}$ https://ejournal.um.edu.my/index.php/JS/article/view/22618/11217.

Nordblom, K. and H. Ohlosson. 2010. Bequest, gifts and education: Links between intergenerational transfers Empirical Econ., 10.1007/s00181-010 0344-0.

Al-Ramly, Shams al-Din bin Abi al-'Abbas Ahmad bin Hamzah bin Shihab al-Din. 1976. Nihayah alMuhtaj ila Syarh al-Minhaj. Jil 4. Kaherah: Maktabah Mustafa al-Halabi.

Resolusi Syariah Bank Negara. 2010. Edisi Kedua. http://www.bnm.gov.my/files/press_release/2010/shariah_resolutions_2nd_edition.pdf. Retrieved: 8 August 2020.

Rusnadewi Abdul Rashid \& Noor Inayah Yaacob. 2010. Hibah: isu pindah milik dan pembatalan hibah hartanah di bawah Kanun Tanah Negara. Shariah Law Report. 1: 14-29.

Rusnadewi Abdul Rashid \& Nasrul Hisyam Nor Muhamad. 2013. Pengurusan harta melalui hibah: kepentingan dandari pelbagai aspek untuk kemajuan ummah. Jurnal Hadhari 5(1): 91-94.

Salleh Buang. 1993. Undang-undang Tanah di Malaysia. Kuala Lumpur: Dewan Bahasa dan Pustaka. 
Al-Sharbini, Muhammad bin Muhammad al-Khaatib. 1994. Mughni al-Muhtaj ila Ma'ani Alfaz alMinhaj. Jil 2-3. Beirut: Dar al-Kutub al- Ilmiyyah.

Al-Suyuty, Jalal al-Din 'Abd al-Rahman. 2013. Al-'Ashbah wa al-Nazair fi Qawaid furu' alShafi'iyyah. Kaherah: Dar al-Salam.

Uzaimah Ibrahim \& Safinar Salleh. 2006. The objective of al-rahn and their achievement in charge/mortgage in Islamic home financing analysis. International Conference on Islamic Jurisprudence and the Challenge of the 21st Century: Maqasid al-Shariah and its Realization in Comtemporary Society, 8-10 August, IIUM.

Wan Kamal Mujani, Rusnadewi Abdul Rashid Wan Mohd Hirwani Wan Hussain. \& Noor Inayah Yaacob. 2012. Gift inter-vivos for charged property. Medwell Journals, The Social Science 7(2): 196-199.

Wan Kamal Mujani, Wan Mohd Hirwani Wan Hussain, Noor Inayah Yaacob \& Rusnadewi Abdul Rashid. 2011. The concept of law of gift inter-vivos under Islamic Law and the Contracts Act 1950. Medwell Journals, International Business Management 5(6): 319-325.

Al-Wizarah al-Awqaf wa al-Syu'un al-Islamiyyah. 2002. Al-Mawsu'ah al-Fiqhiyyah. Jil. 45. Kuwait: Wizarah al-Awqaf wa Syu'un Islamiyyah.

Al-Zuhayli, Wahbah Mustafa. 2012. Al-Fiqh al-Islami wa Adillatuh. Jil 4. Damshiq: Dar al-Fikr. 